\begin{tabular}{|cc|c|}
\hline ISSN (Online): 2367-6957 & ISSN (Print): 2367-6361 \\
Izvestiya Journal of Varna University of Economics 4 (2020) & I Z V E S T I Y A \\
Journal of Varna University of Economics \\
http://journal.ue-varna.bg
\end{tabular}

\title{
BOARD DIVERSITY AND SUSTAINABILITY REPORTING: EVIDENCE FROM INDUSTRIAL GOODS FIRMS
}

\section{Saidu MUSA ${ }^{1}$, Nusirat Ojuolape GOLD ${ }^{2}$, Hope Osayantin AIFUWA ${ }^{3}$}

1 Department of Accounting and Finance, Kwara State University, Malete, Kwara State, Nigeria. E-mail: musasaidu.aca2010@gmail.com

2 Department of Accounting and Finance, Kwara State University, Malete, Kwara State, Nigeria, E-mail: nusiratgold@gmail.com

3 Department of Accounting, Faculty of Management Sciences, University of Benin, Benin City, Edo State, Nigeria. E-mail: aifuwahopeosayantin@gmail.com

\section{JEL: M10, M14, M41, M48 Abstract}

The sustainable development goals (SDGs) adopted by all the United Nations member countries were to reduce the social and ecological outcome of businesses and governments across the globe, among others. Businesses can key into this agenda by disclosing their economic, environmental and social impact in their financial reports. However, in Nigeria, the extent of sustainability reporting amongst firms is still low and not a listing requirement. Against this backdrop, this study investigated the influence of a diverse board on the extent of sustainability reporting in listed industrial goods firms on the Nigerian Stock Exchange from the period 2014-2018. We developed a sustainability disclosure index using the Global Reporting Initiative (GRI) guidelines to score the information content of annual reports relating to sustainability performance. Nationality, age and educational level were used to proxy diversity in the boardroom. The study also used descriptive and inferential statistics to summarize the data and to draw an inference on the population studied. Our study failed to validate the theoretical framework - StakeholderDependency Theory used in the study, as results from the panel least squares regression revealed that age diversity in the boardroom negatively and significantly affects the extent of sustainability reporting. Furthermore, we found no evidence on the nexus between

\section{Key words:}

Nationality diversity; Age diversity; Education level diversity; Sustainability Reporting; Global Reporting Initiative, Nigeria. nationality diversity and sustainability reporting; and education level diversity and sustainability reporting. The study concluded that diversity in boardroom influences the extent of sustainability reporting in Nigeria. This study recommends that firms should increase the representation of foreign directors in the boardroom because they add value and a wealth of experience to the board.

(C) 2020 University of Economics - Varna

Citation: MUSA, S., GOLD, N. O., AIFUWA, H. O. (2020). Board Diversity and Sustainability Reporting: Evidence from Industrial Goods Firms. Izvestiya Journal of Varna University of Economics, 64 (4), p. 377 - 398. DOI: 10.36997/IJUEV2020.64.4.377 


\section{Introduction}

Sustainability Reporting (SR) is an emerging voluntary reporting initiative across the globe in recent times. The idea was brought into the limelight following the 1987 Brundtland Report in bridging the gap between environmental and human development concerns (Bebington, \& Larrinaga, 2014; Bebington, \& Unerman, 2017). The concept was further popularised in academic literature and business environment following the United Nation's (UN) adoption of the Organization for Economic and Community Development's (OECD) eleven (11) Millennium Development Goals (MDGs) which was transformed into Seventeen (17) Sustainable Development Goals (SDGs) in 2015 (Bebington, \& Unerman, 2017; UN SDG, 2015). The SDGs aim to address poor business and government's social, ecological and economic outcome. This poor businesses and government outcomes over time have resulted in the increased occurrences of natural disasters like flooding, earthquakes, and the increase in carbon emission as well as pollution (water and air), social inequalities and poverty (Chong, 2019; Manning, Braam \& Reimsbach, 2019; Elaigwu, Ayoib \& Salau, 2020). Hence, specifically, business firms in particular can contribute to the attainment of the goals through sustainability reporting.

However, it is sad to know that Sustainability Reporting (SR) has not been widely accepted or recognised as part of a business model for successful performance and survival by firms across the globe (Johari \& Komathy, 2019). Although in 2019, Johari and Komathy (2019) observed that Europe had the highest sustainability disclosure rate of about forty-nine per cent, followed by Asia with fifteen per cent, North America fourteen per cent. They also observed the following disclosure rate: Latin America twelve per cent (12\%), Oceania six per cent $(6 \%)$ and Africa with the least disclosure rate of only four per cent (4\%). The low compliance and disclosure rate could be attributed to the nature of the report - being voluntary. The nature of this report also makes the enforcement to lack regulatory and legal backing. In Nigeria, it is the same scenario: low compliance and disclosure rate of social and environmental issues among firms in the community where they operate (Adeniyi \& Fadipe, 2018; Awodiran, 2019).

The board as one of the corporate governance mechanisms helps to protect the interests of business owners and other stakeholders. Their duty of overseeing and monitoring the reporting process makes them very important to the success and survival of a firm (Aifuwa \& Embele, 2019; Saidu \& Aifuwa, 2020). On sustainability reporting, a diverse board is far better in overseeing and monitoring the reporting of non-financial information of a firm (Michelon \& Parbonetti, 2012). With their unique attributes, they 
would improve the firm's strategic decision quality and identify and fulfil stakeholders needs (de Jong \& van der Meer, 2017; Michelon \& Parbonetti, 2012).

Diversity in the boardroom comes in different dimensions (nationality, race, gender, education level, educational background; experience). However, in this study, we examined nationality, age and education level diversity. In line with the agency theory, a board with a high proportion of foreign directors will increase agency cost and may cause poor performance in firms (Masulis, Wang \& Xie, 2016). Thus, this negates the aim of a firm to maximise profit and minimise cost. In age diversity, the presence of both young and old directors may limit the board information processing speed. Specifically, having older directors above sixty (60) years leaves a fragment of the board redundant. According to the Nigerian Constitution, the attainment of the retirement age of sixty (60) years means the individual becomes unproductive. Thus, employing unproductive people on the board will not improve the extent of sustainability reporting. Lastly, an inferiority complex could set in between directors with different levels of experience. It would hinder their board relationship in resolving agency problems and reporting sustainability issues.

In sum, the purpose of this study is to investigate the influence of a diverse board on sustainability reporting in Nigeria. The choice of our explanatory variables (nationality, age and educational level) motivated the study. There seem to be mixed findings on the nexus between nationality diversity in the boardroom and sustainability reporting (see Sharif \& Rashid, 2014; Fuente, Garcia-Sanchez \& Lozano, 2017; Zaid, Wang, Adib, Sahyouni \& Abuhijleh, 2020; Huijsman, 2017; Hesselink, 2017; Janggu, Darus, Zain \& Sogamoi, 2014; Rodriquez-Ariza, GarciaSanchez \& Frias-Aceituno, 2012; and Khan, Khan \& Semturk, 2019a; Ibrahim \& Hanifah, 2016; Khan, Khan \& Saeed, 2019; Berger, 2019). Also, there is a dearth in literature on the nexus between age diversity, educational level diversity in the boardroom and sustainability reporting (see Baker, Ghazali \& Ahmad, 2019: King'ori, Naibei, Sand \& Kipkosgei, 2019; Janggu, Darus, Zain \& Sawani, 2014). Against these backdrops, this study raised the following research questions:

- What is the effect of nationality diversity in the boardroom on sustainability reporting?

- What is the impact of age diversity in the boardroom on sustainability reporting?

- What is the influence of educational level diversity in the boardroom on sustainability (reporting)?

The preliminary results of the study bolster the need for a large board size in listed manufacturing firms (specifically in the industrial goods sector) on the Nigerian 
Stock Exchange to promote diversity on the board. This would also improve their sustainability disclosure rate. The result of the descriptive statistics in Table 2 reported means of approximately $42 \%$ sustainability disclosure rate with $19 \%$ of foreign directors. Also, about $35 \%$ of the directors on the board were below sixty (60) years of age, and $96 \%$ of them had a higher degree qualification (MSc and $\mathrm{PhD}$ ). The result from the inferential statistic did not support the Stakeholder-Dependency Theory. The result of the association between age diversity in the boardroom and sustainability reporting is negative and statistically significant, which is contrary to our apriori expectation of a positive relationship. The result shows that the presence of older board members on the board will not promote the idea of sustainability reporting. The result, however, is not unexpected, looking at high profile environmentally and socially scandalous firms like British Petroleum (BP) oil spillage in the Gulf of Mexico, Chernobyl nuclear power plant explosion in Russia, Exxon Valdez oil spill in the waters of Alaska, Kuwait oil well fires and Lonmin Markana mining maltreatment of its workers in South Africa, to mention a few. The study made a modest contribution to the existing literature by showing that the influence of both boards demographic and cognitive diversity on sustainability reporting.

We organised the rest of the paper as follows: Section two focuses on the literature review and hypotheses development. Section three addresses the method with emphasis on theoretical framework and model specification. Section four presents data analysis, interpretation and discussion of findings. Section five concludes.

\section{Literature Review and Hypotheses Development}

\section{Sustainability Reporting}

According to Aifuwa (2020) and Aifuwa, Saidu, Enehizena and Osazevbaru (2019), sustainability reporting is a blend of two concepts: "sustainability" and "reporting". Sustainability, as defined by Brundtland (1987), is meeting the needs of the current generation without compromising the ability of the next generations to meet their own needs. Reporting means disclosing an organisation's information fully or partially to stakeholders (Aifuwa, 2020). Therefore, sustainability reporting is disclosing organisational information about its daily economic, social and environmental activities as it affects the society and stakeholders where it operates. Global Reporting Initiative [GRI] (2019) defined sustainability reporting, performance or disclosure as the process whereby organisations provide information about the economic, environmental and social impact caused by its everyday 
activities. Flowing from the GRI definition on sustainability reporting, visibly, there are enormous benefits to be derived from disclosing economic, social and environmental issues. Aifuwa et al. (2019) opined that the benefits of sustainability reporting include better financial performance, improved firm reputation, the attraction of better investors and high morale among employees.

However, despite these envisaged benefits, there are some issues in disclosing economic, environmental and social effects an organisation has on the environment. These issues include measurement and disclosure, motivation, enforcement and compliance, standardisation, and the comparability \& reliability of the report (Muñoz, Zhao, \& Yang, 2017). In Nigeria, sustainability disclosure rate is low among firms because of the voluntary nature of the report, and also not being a listing requirement for firms on the Nigerian capital market (Asaolu, Agboola, Ayoola, \& Salawu, 2011; Emeka-Nwokoji \& Osisioma, 2019; Haladu \& Salem, 2016; Nwobu, 2017; Oyekwelu \& Eke, 2014).

Notwithstanding the adoption of the GRI framework by the Nigerian stock exchange in 2018 and also the recognition of sustainability disclosure in the Nigerian code of corporate governance of 2018, there still exists a low compliance rate in disclosing environmental and social issues (Aifuwa et al., 2019). However, some countries like Brazil, China, Denmark, Hong Kong, India and Malaysia have made great strides in making the report mandatory (Ioannis \& Serafeim, 2014). GRI seems to be the most popular framework in reporting sustainability issues (Johari \& Komathy, 2019). However other frameworks or guidelines also exist, such as the Carbon Disclosure Project (CDP), International Standard Organization (ISO), Greenhouse Gas Protocol and United Nations Global Compact (UNGC), Sustainability Accounting Standards Board (SASB), International Integrated Reporting Council (IIRC) (Aifuwa, 2020; Aifuwa et al., 2019; Nwobu, 2017).

\section{Board Diversity}

The concept of 'board diversity' has emerged as the most prominent issue in corporate governance literature in recent times (Rhode \& Packel, 2014; Ibrahim \& Hanefah, 2016). Ayuso and Argandona (2009) and Van Knippenberg, De Dreu and Homan (2004) defined board diversity as the heterogeneity amongst directors on the board with unique attributes or dimensions. The dimensions of a diverse board can be grouped into observable difference (like race, ethnic background, nationality, gender and age) and less discernible diversity (educational level, educational background, functional and occupational background, industry experience and organisational membership) (Kang, Chen \& Gray, 2007). 
The importance of diversity in the boardroom cannot be overemphasised, as it fosters better decisions and brings about innovation in an organisation (Aifuwa \& Embele, 2019). Kyaw, Olugbode and Petracci (2017) stated that a more diverse board could attract more resources into an organisation. Rathnayaka (2018) and Michelon and Parbonetti (2012) argued that a diverse board would improve the quality of a firm's strategic decision. Furthermore, Arora and Sharma (2016) and Butler (2012) argued that diversity in the boardroom would improve a firm's performance and reputation, as also its global existence. Drawing inspiration from the above arguments, this study envisages that board diversity will positively affect sustainability reporting in firms. Therefore, in this study, we examined the impact of nationality, age and education level diversity on sustainability reporting.

\section{Board Member Nationality and Sustainability Reporting}

Nationality diversity reflects the presence of foreign directors of different nationalities in the boardroom. Oxelheim and Randey (2003) asserted that foreign directors are deeply devoted to the firm's transparency, accountability and reputation in the competitive market. In line with this, Zaid et al. (2020) echoed that nationality diversity is one of the modern drivers of corporate sustainability reporting in the present-day business world. A board with a high representation of foreign directors from different nationalities brings a diverse idea and perspective to the boardroom (Ferrero-Ferrero, Fernandez-Izquierdo \& Munoz-Torres, 2015). This is because of their international market engagement, diverse professional background, religion, language, life experience, knowledge and culture which may lead to improved decision making in particular (Ferrero-Ferrero et al. 2015), and enhanced boardroom performance (Estelyi \& Nisar, 2016).

Notwithstanding the above assertions on the positive impact of the presence of foreign directors in the boardroom, Masulis et al. (2016) argued that a nationally diverse board would cause poor performance because of the high cost of foreign directors and ineffective monitoring oversight. Also, empirical literature evidenced no relationship between a nationally diverse board and sustainability reporting (Sharif \& Rashid, 2014; Fuente et al., 2017; Zaid et al., 2020; Huijsman, 2017; Hesselink, 2017; Janggu et al., 2014; Rodriquez-Ariza et al., 2011). However, Khan et al., (2019a); Ibrahim and Hanifah (2016); Khan et al., (2019b); and Berger (2019) found a positive relationship between foreign directors on the board of an organisation and sustainability reporting. This study, therefore, hypothesises that;

$\mathrm{Ho}_{1}$ : Nationality diversity in the boardroom has no significant effect on sustainability reporting 
S. Musa, N. O. Gold, H. O. Aifuwa. Board Diversity and Sustainability Reporting: Evidence from Industrial Goods Firms

\section{Board Member Age and Sustainability Reporting}

Age diversity reflects the existence of both old and young directors on the board. Darmadi (2011) asserted that age diversity in the board creates value and diverse views on the social economic and political environment in a firm. Ali, $\mathrm{Ng}$, and Kulik (2014) argue that age diversity in the board leads to transfer of knowledge, skills and experience from older directors to younger directors, which may lead to better decision making and increased effectiveness in the board. Abdullah and Ismail (2013) emphasised the importance of age diversity in the board (and added) that it significantly reduces business in leadership and decision-making style of same age group members.

However, some studies claimed that boards comprising older directors are likely to disclose more non-financial information of a firm (Hasfi \& Turgut, 2013; Post, Rahman \& Rubow, 2011). They based their argument on the fact that age reflects the director's experience in business and that they are more sensitive towards social and environmental issues. Empirically, little or no studies have been carried out on the nexus between age diversity in the boardroom and sustainability reporting in Nigeria. Baker et al., (2019) found no significant difference between the ages of directors on the board to the extent of sustainability reporting, implying that age diversity in the boardroom does not bear a significant relation to sustainability reporting. Therefore, this study hypothesises that;

\section{$\mathrm{Ho}_{2}:$ Age diversity in the boardroom has no significant impact on sustainability reporting}

\section{Board Member Education Level and Sustainability Reporting}

Diversity in the level of education on the board reveals the existence of directors with both low and high level of education. The presence of directors with different levels of education on the board leads to advanced thinking capacity. Hsu, Chen and Cheng (2013) assert that diversity in the level of education on the board improves the directors' ability and proficiency in processing information and recognising fresh business opportunities. Diversity in the level of education in the boardroom leads to the generation of alternative ideas on strategic issues on non-financial disclosure (Katmon, Mohamad, Norwani \& Farooque, 2017). Khan et al. (2019b) argue that education level diversity of directors would help in solving the board's problem in a sophisticated and strategic directional manner. Therefore, directors with both low and high education qualifications would help the board to resolve economic, environmental and social issues in an organisation. However, it is sad that they have 
done few empirical studies on the nexus between the education level diversity in the boardroom and sustainability reporting. King'ori et al., (2019) and Janggu et al. (2019) found that the education qualification of the directors on the board positively affects sustainability reporting. Thus; this study hypothesises that;

\section{Ho $_{3}$ : Education level diversity in the boardroom has no significant influence on sustainability reporting}

\section{Control Variables}

This study introduced two firm-specific variables to control the dependent variable. The variables are firm age and firm size. Haladu and Beri (2016) submitted that older firms are (more) socially and environmentally responsible than younger firms. Leaning on this empirical evidence, we envisage likewise in our study. Secondly, the size of the firm is another determinant of sustainability reporting. Prior studies have argued that a firm's size positively affects the extent of sustainability disclosure (Hesselink, 2017; Ong, 2016, Aman \& Baker, 2018; Awodiran, 2019; Hu $\&$ Loh, 2018). Thus, leaning on these empirical pieces of evidence, our study also envisages likewise.

\section{Material and Methods}

\section{Theoretical Framework}

This study hinges on the Stakeholders theory of (Freeman, 1984) and the Resource Dependency theory of (Pfeffer \& Salancik, 1978) to explain and understand the influence of a diverse board on sustainability reporting in Nigeria. The Stakeholder theory explains the tripartite relationship that exists between the principal (owner of a firm), agent (managers/board of directors) and stakeholders (suppliers, local community, investors and the public) (Aifuwa, Embele, \& Saidu, 2018). The theory addresses the expectations of specific stakeholder groups in society and considers the effect of their expectation on information disclosure, bearing in mind the existence of more powerful stakeholders (Font, Guix \& Bonilla-Preigo, 2016; Ngu $\&$ Amran, 2018). Therefore, the survival of a firm's business hugely depends on the support of the stakeholders; hence, they must adjust their business model to address stakeholders' concerns and needs. To achieve this, we cannot ignore a diverse board. The Resource dependency theory stressed that the board as one of the vital resources in a firm has a significant impact on the strategic decision making and disclosing information (Pfeffer \& Salancik, 1978; Hasfi \& Turgut, 2013). Fasan and Moi (2016) argued that board members play a vital role in influencing information disclosure to minimise environmental uncertainties and external interdependency. Therefore, in 
S. Musa, N. O. Gold, H. O. Aifuwa. Board Diversity and Sustainability Reporting: Evidence from Industrial Goods Firms

line with the stakeholders and resource dependency theory, the principal of the firm must use the services of a diverse board to meet the needs of stakeholders in reporting the economic, social and environmental issues. Based on the unique qualities that diverse boards possess, issues on sustainability reporting will be resolved swiftly and increase the performance and reputation of the firm (Baker et al., 2018; Ngu \& Amran, 2018). In line with the Stakeholder-Dependency theory, this study proposes that a diverse board will increase the extent of sustainability reporting.

\subsection{Model Specification}

In line with the theoretical framework of the study, we recognised sustainability reporting as a dependent variable. In contrast, board member nationality, age and education were identified as the independent variable of the study.

$\underline{\text { Independent variable }}$

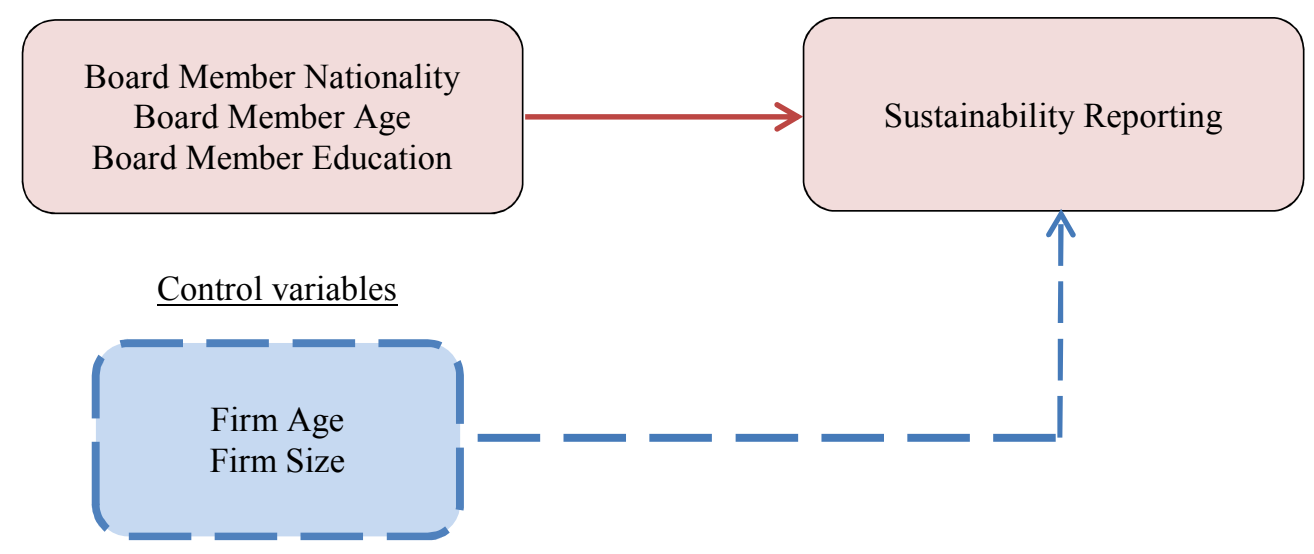

Fig. 1. Schematic representation of the variables of the study

Flowing from the theoretical framework and the existing literature, we specified the model as;

In functional form;

$\mathrm{SNR}=f(\mathrm{BMN} ; \mathrm{BMA} ; \mathrm{BME} ; \mathrm{FAGE} ; \mathrm{FSZE})$

In econometric form:

$$
\begin{aligned}
& \mathrm{SNR}=\beta_{0}+\beta_{1} \mathrm{BMN}_{\mathrm{it}}+\beta_{2} \mathrm{BMA}_{\mathrm{it}}+\beta_{3} \mathrm{BME}_{\mathrm{it}}+ \\
& +\beta_{4} \mathrm{FAGE}_{\mathrm{it}}+\beta_{5} \mathrm{FSZE}_{\mathrm{it}}+\varepsilon_{\mathrm{it}}
\end{aligned}
$$


Where

SNR = Sustainability Reporting;

$\beta_{0}=$ Constant;

$\mathrm{BMN}=$ Board Member Nationality;

BMA = Board Member Age;

$\mathrm{BME}=$ Board Member Education;

$\mathrm{FAGE}=$ Firm Age; and

$\mathrm{FSZE}=$ Firm Size.

$\beta_{1}, \beta_{2} \beta_{3}=$ Coefficient of explanatory variables

$\varepsilon=$ Standard error

$\mathrm{i}=$ Cross sectional (Companies)

$\mathrm{t}=$ Time Series

A priori expectations is in with the theoretical framework to be $\beta_{1,} \beta_{2}, \beta_{3}, \beta_{4}, \beta_{5}>0$

\subsection{Development of Sustainability Disclosure Index (SDI)}

We recognised sustainability reporting as the study's dependent variable. In developing the sustainability reporting index, we will use the GRI G4 general framework, which is made (of) economic, environmental and social indicators. Afterwards, we employed content analysis to develop weighted sustainability disclosure index for the economic, environmental and social performance of the sampled firms. If firms fully disclosed economic, environmental and social information, they were awarded one, while zero for non-disclosure, respectively.

$$
\text { Therefore, } \mathrm{SNR}=\frac{T D}{M}
$$

Where;

SNR $=$ Sustainability Reporting

$\mathrm{TD}=$ Total disclosure $(\mathrm{N} 1+\mathrm{N} 2+\mathrm{N} 3)$

$\mathrm{N} 1$ = for the economic indicator $\mathrm{i}$

$\mathrm{N} 2$ = for the environmental indicator $\mathrm{i}$

$\mathrm{N} 3$ = for the social indicator $\mathrm{i}$

$\mathrm{M}=$ Maximum possible score 
S. Musa, N. O. Gold, H. O. Aifuwa. Board Diversity and Sustainability Reporting: Evidence from Industrial Goods Firms

Table 1

\section{Measure of variables}

\begin{tabular}{|c|c|c|c|}
\hline Variable & Type & Measurement & Supporting Scholars \\
\hline $\begin{array}{l}\text { Sustainability } \\
\text { Reporting }\end{array}$ & $\begin{array}{l}\text { Dependent } \\
\text { Variable }\end{array}$ & $\begin{array}{l}\text { GRI G4 framework on } \\
\text { economic, social and } \\
\text { environmental } \\
\text { sustainability } \\
\text { disclosure; at stated } \\
\text { above }\end{array}$ & $\begin{array}{l}\text { GRI (2013); } \\
\text { Anazonwu Egbunike } \\
\text { \& Gunardi (2018) }\end{array}$ \\
\hline $\begin{array}{l}\text { Board Member } \\
\text { Nationality }\end{array}$ & $\begin{array}{l}\text { Independent } \\
\text { Variable }\end{array}$ & $\begin{array}{l}\text { Number of foreign } \\
\text { directors sitting on the } \\
\text { board divided by total } \\
\text { number of directors }\end{array}$ & $\begin{array}{l}\text { Anazonwu et al } \\
(2018)\end{array}$ \\
\hline Board Member Age & $\begin{array}{l}\text { Independent } \\
\text { Variable }\end{array}$ & $\begin{array}{l}\text { Dichotomous index; } 1 \text { if } \\
\text { the average age of the } \\
\text { board of directors is less } \\
\text { than } 60 \text { years, else } 0 .\end{array}$ & $\begin{array}{l}\text { Abdullah \& Ismail } \\
\text { (2013); Baker et al } \\
\text { (2019). }\end{array}$ \\
\hline $\begin{array}{l}\text { Board Member } \\
\text { Education }\end{array}$ & $\begin{array}{l}\text { Independent } \\
\text { Variable/ }\end{array}$ & $\begin{array}{l}\text { Dichotomous index; } 1 \text { if } \\
\text { the board has directors } \\
\text { with second or third } \\
\text { degree, else, } 0\end{array}$ & \\
\hline Firm Age & $\begin{array}{l}\text { Control } \\
\text { Variable }\end{array}$ & $\begin{array}{l}\text { Number of years since } \\
\text { the time the company } \\
\text { was quoted on the floor } \\
\text { of the Nigerian Stock } \\
\text { (Exchange) }\end{array}$ & $\begin{array}{l}\text { Emeka-Nwokeji \& } \\
\text { Osisioma (2019) }\end{array}$ \\
\hline Firm Size (FSZE) & $\begin{array}{l}\text { Control } \\
\text { Variable }\end{array}$ & $\begin{array}{l}\text { Natural logarithm of } \\
\text { total assets }\end{array}$ & $\begin{array}{l}\text { Aifuwa \& Embele } \\
\text { (2019); Saidu \& } \\
\text { Aifuwa (2020); } \\
\text { Aifuwa, Musa \& Gold } \\
\text { (2020) }\end{array}$ \\
\hline
\end{tabular}

Source: Authors' Compilation, 2020.

\subsection{Research Design}

This study adopted the multi-method quantitative research design. We chose this design in the study because it is inclined on the positivist research philosophy and deductive approach. Also, it examines relationships between variables measured numerically and analysed using a range of statistical and graphical techniques (Saunders, Lewis \& Thornhill, 2016). 


\subsection{Method of Data Collection and Analysis}

The population comprises manufacturing firms on the Nigerian Stock Exchange. The target population of the study was the industrial goods sector listed on the Nigerian Stock Exchange as of December 2018. We preferred these firms because their activities revolve around the three dimensions of sustainability reporting (Awodiran, 2019). This study sampled all thirteen (13) companies in the sector to have a sound basis for generalisation (Aifuwa \& Okojie, 2015). The study also utilised secondary data (audited financial statements) from the Nigerian Stock Exchange spanning from 2014 to 2018. Descriptive and inferential statistics were used to analyse data. The Panel least squares were used to test hypotheses stated because the data include properties of time-series and cross-sectional data.

\section{Data Presentation, Analysis and Discussion of Findings}

Table 2

\section{Descriptive Statistics for Secondary data}

\begin{tabular}{|l|r|r|r|r|r|r|}
\hline & \multicolumn{1}{|c|}{ SNR } & \multicolumn{1}{c|}{ BMN } & \multicolumn{1}{c|}{ BMA } & \multicolumn{1}{c|}{ BME } & \multicolumn{1}{c|}{ FAGE } & \multicolumn{1}{c|}{ FSZE } \\
\hline Mean & 0.4242 & 0.1927 & 0.3529 & 0.9608 & 28.9412 & 6.5788 \\
\hline Median & 0.3333 & 0.0000 & 0.0000 & 1.0000 & 30.0000 & 6.3575 \\
\hline Maximum & 0.7273 & 0.5900 & 1.0000 & 1.0000 & 44.0000 & 8.7897 \\
\hline Minimum & 0.0606 & 0.0000 & 0.0000 & 0.0000 & 5.0000 & 5.4186 \\
\hline Std. Dev. & 0.1892 & 0.2191 & 0.4826 & 0.1960 & 10.3042 & 0.8634 \\
\hline
\end{tabular}

Source: Authors' Computation, 2020.

Table 2 presents the summary statistics about the sampled firms over the study period. The mean proportion of companies providing sustainability disclosures was $42.4 \%$ while companies with the highest disclosure had $72.7 \%$ of the GRI disclosures reported. The lowest disclosure recorded was $6 \%$. The mean value of the proportion of foreign directors, directors' age, and level of education, firm age and firm size were $19.3 \%, 35 \%, 96 \%, 28$ years and nine months and NGN 6,579,000 respectively. The highest value in the proportion of foreign directors, firm age and firm size was $59 \%$, 44 years, and NGN 8,789,701,000 respectively. Lastly, the standard deviation in the ratio of foreign directors and the ages of directors did not exhibit considerable clustering around the mean. 
S. Musa, N. O. Gold, H. O. Aifuwa. Board Diversity and Sustainability Reporting: Evidence from Industrial Goods Firms

Table 3

\section{Correlation Matrix}

\begin{tabular}{|l|r|r|r|r|r|r|}
\hline & \multicolumn{1}{|c|}{ SNR } & \multicolumn{1}{c|}{ BMN } & \multicolumn{1}{c|}{ BMA } & \multicolumn{1}{c|}{ BME } & \multicolumn{1}{c|}{ FAGE } & \multicolumn{1}{c|}{ FSZE } \\
\hline SNR & 1.0000 & 0.4829 & 0.1725 & 0.1797 & 0.4112 & 0.6165 \\
\hline BMN & & 1.0000 & -0.1927 & 0.1795 & 0.4181 & 0.6328 \\
\hline BMA & & & 1.0000 & 0.1492 & -0.4100 & 0.1395 \\
\hline BME & & & & 1.0000 & 0.3256 & 0.1745 \\
\hline FAGE & & & & & 1.0000 & 0.3278 \\
\hline FSZE & & & & & & 1.0000 \\
\hline
\end{tabular}

Source: Authors' Computation, 2020.

The linearity of variables (correlation matrix) as presented in Table 3 show that the variables exhibited both positive and negative relationship. Nationality diversity and sustainability reporting (0.483), age diversity and sustainability reporting (0.173), education level diversity and sustainability reporting (0.180), firm age and sustainability reporting $(0.411)$, firm size and sustainability reporting $(0.617)$ and age diversity and sustainability reporting $(-0.193)$. As seen in the matrix, the strength of the relationship between variables measured by the Pearson product-moment correlation showed that the association between the variables is relatively small and were below the threshold of 0.80 , suggesting the absence of the problem of multicollinearity in the predictor variables (Studenmund, 2014)

\subsection{Multivariate Analysis}

This study presents the result of the Hausman test and the Partial Least Squares Regression in this section. The study tested the hypotheses at a 5\% level of significance (that is if p-value $<0.05$ reject $\mathbf{H o}$, else do otherwise).

Table 4

\section{Hausman test of effect specification}

Correlated Random Effects - Hausman Test

\begin{tabular}{|lrrr}
\hline \hline Test Summary & Chi-Sq. Statistic & Chi-Sq. d.f. & \multicolumn{2}{l}{ Prob. } \\
\hline \hline Cross-section random & 16.8242 & 5 & 0.0048 \\
\hline
\end{tabular}

Source: Authors' computation, 2020. 
The table above shows the result of the Hausman test, HM (5) $=16.82, \mathrm{p}=$ 0.0048 . This study ignored the random effect model because the p-value was less than $5 \%$. The study, therefore, accepted the fixed effect model of the Panel least squares regression.

Table 5

Fixed effect panel regression

\begin{tabular}{lrcrr}
\hline \multicolumn{1}{c}{ Variable } & Coefficient & Std. Error & \multicolumn{1}{c}{ t-Statistic } & \multicolumn{1}{c}{ Prob. } \\
\hline \hline C & 0.8046 & 0.8089 & 0.9947 & 0.3267 \\
BMN & 0.1219 & 0.2646 & 0.4608 & 0.6478 \\
BMA & -0.3012 & 0.0603 & -4.9928 & 0.0000 \\
BME & -0.0224 & 0.0725 & -0.3088 & 0.7593 \\
FAGE & 0.0095 & 0.0082 & 1.1626 & 0.2529 \\
FSZE & -0.0838 & 0.1369 & -0.6122 & 0.5443 \\
\hline \hline \multicolumn{5}{c}{} \\
\hline Cross-section fixed (dummy variables) & & \\
\hline \hline R-squared & 0.9236 & Mean dependent var & 0.4242 \\
Adjusted R-squared & 0.8909 & S.D. dependent var & & 0.1892 \\
S.E. of regression & 0.0625 & Akaike info criterion & -2.4562 \\
Sum squared resid & 0.1367 & Schwarz criterion & -1.8501 \\
Log likelihood & 78.6323 & Hannan-Quinn criter. & -2.2246 \\
F-statistic & 28.2220 & Durbin-Watson stat & 2.4661 \\
Prob(F-statistic) & 0.0000 & & \\
\hline \hline
\end{tabular}

Source: Authors' computation, 2020.

The result of the Panel least squares (fixed effect) revealed in Table 5 that board diversity influences sustainability reporting in Nigeria, as the F-statistic $=28.222, \mathrm{p}=$ 0.0001 . Also, the Adjusted R-Squared stood at 0.8909 , that is about $89 \%$ of the systematic variation in the dependent variable is caused by the explanatory variable used in the study. In comparison, about $11 \%$ of the change is caused by other variables not included in the model but were adequately captured by the standard error of the regression, $\mathrm{SE}=0.0625$. The Durbin-Watson statistics of 2.46 indicates negative autocorrelation in the sample.

On the hypotheses, we found out that nationality diversity in the boardroom has a positive but insignificant effect on sustainability reporting, $\mathrm{t}=0.4607, \beta_{1}=$ 
S. Musa, N. O. Gold, H. O. Aifuwa. Board Diversity and Sustainability Reporting: Evidence from Industrial Goods Firms

$0.122, p=0.648$. This study failed to reject the null hypothesis stated. This result partially supports the resource dependency theory and disagrees with the argument of Masulis, et al., (2016) that a nationally diverse board will cause poor performance because of the high cost of foreign directors and ineffective monitoring oversight. Also, our finding is consistent with the work of (Sharif \& Rashid, 2014; Fuente et al., 2017; Zaid et al., 2020; Huijsman, 2017; Hesselink, 2017; Janggu et al., 2014; Rodriquez-Ariza et al., 2011): they found no evidence on the nexus between a nationally diverse board and sustainability reporting. However, it sharply deviates from the findings of Khan et al., (2019a); Ibrahim and Hanifah (2016); Khan et al., (2019b); and Berger (2019) which found a positive and significant relationship between foreign directors on the board of an organisation and sustainability reporting.

Secondly, the study discovered that age diversity in the boardroom has a negative and significant impact on sustainability reporting, $\mathrm{t}=-4.992, \beta_{2}=-0.301, p=$ 0.0001 . Hence, the study failed to accept the null hypothesis stated in it. This result supports the position of the constitution of the Federal Republic of Nigeria that older directors (60 years and above) will (prove) non-productive on the board of an organisation. However, the study failed to agree with the stakeholder-resource dependency perspective that age diversity on the board promotes sustainability reporting. This finding is in dissonance with the work of Baker et al., (2019) (which) found no significant difference between the ages of directors on the board (in the effect) on the extent of sustainability reporting, implying that that age diversity in the boardroom does not have a significant relation to sustainability reporting.

On education level diversity, we found a negative and insignificant nexus on sustainability reporting, $\mathrm{t}=-4.992, \beta_{3}=-0.301, \mathrm{p}=0.7593$. This implies that educational level diversity of directors in the boardroom has no significant influence on sustainability reporting. This result supports the stakeholder-resource dependency perspective that diversity in the director's education level would promote sustainability reporting. Also, this result disagreed with the views of Khan et al., (2019b) that education level diversity of directors would help in solving the board's problem in a sophisticated and strategic directional manner. Also, this finding is in contradiction with the studies of King'ori, et al., (2019) and Janggu et al., (2014). They submitted that the education qualification of the directors on the board positively affects sustainability reporting. Lastly, firm age and firm size were statistically not related to sustainability reporting, $t=1.162, \beta_{4}=0.0095, p=0.253$ and $\mathrm{t}=-0.612, \beta_{5}=-0.083, \mathrm{p}=0.5443$ respectively. 


\section{Conclusion and Recommendations}

The broad objective of this study was to examine the influence of a diverse board on sustainability reporting in industrial goods firms in Nigeria. Specifically, the study examined the impact of nationality, age and educational level diversity in the boardroom on the extent of sustainability reporting in the listed industrial goods firms in Nigeria. The descriptive statistics revealed that sustainability disclosure rate was about $42 \%$, and the proportion of foreign directors was about $19 \%$. Also, about $35 \%$ of the directors on the board were below sixty (60) years of age, and $96 \%$ of them had a higher degree qualification (MSc and PhD). Hence, owing to these findings in the result of the descriptive statistics, listed industrial goods firms will not be contributing to the attainment of the UN SDGs before 2030 as envisaged. This claim was further bolstered in our inferential statistics results. Based on the overall findings of this study, listed industrial firms must do more to change the current narratives, as regards their environmental and social performance. Hence, we, therefore, recommend that: firms should increase the representation of foreign directors in the boardroom because they add value and a wealth of experience to the board; the representation of younger directors should be increased in the boardroom to have a vibrant board, and firms should encourage more directors with a first degree in the boardroom to have a mix of knowledge resource.

This study is subject to some limitations. First, we only studied listed industrial goods firms in the manufacturing industry, thereby ignoring the unlisted industrial goods firms. Thus, generalisations should be made with caution. Secondly, the period studied - 2014-2018 may not accurately capture the subject of the study. This study, therefore, recommends that future research should cut across the other unlisted industrial goods firms and the period of study should be increased.

\section{References}

1. Abdullah, S. N., \& Ismail, K. N. I. K. (2013). Gender, ethnic and age diversity of the boards of large Malaysian firms and performance. Jurnal Pengurusan, 38, $27-40$.

2. Adeniyi, S. I., \& Fadipe, A. O. (2018). Effect of board diversity on sustainability reporting in Nigeria: A study of beverage manufacturing firms. Indonesian Journal of Corporate Social Responsibility and Environmental Management, 1(1), 43-50.

3. Aifuwa, H. O. (2020). Sustainability reporting and firm performance in developing climes: A review of literature. Copernican Journal of Finance and Accounting, 9(1) Forthcoming 
S. Musa, N. O. Gold, H. O. Aifuwa. Board Diversity and Sustainability Reporting: Evidence from Industrial Goods Firms

4. Aifuwa, H. O. \& Embele, K. (2019). Board characteristics and financial reporting quality. Journal of Accounting and Financial Management, 5(1), 30-49.

5. Aifuwa, H. O., Embele, K., \& Saidu, M. (2018). Ethical accounting practices and financial reporting quality. EPRA International Journal of Multidisciplinary Research, 4(12), 31-44.

6. Aifuwa, H. O \& Okojie, P. I. (2015). Materials and methods: SPSS demystified. Unpublished manuscript, Samuel Adegboyega University, Ogwa, Nigeria.

7. Aifuwa, H. O., Musa, S. \& Gold, N. O. (2020). Audit committee attributes and the timeliness of corporate financial reporting in Nigeria. Accounting and Finance, 88(2), 114-124. DOI https://doi.org/10.33146/2307-9878-2020-2(88)-114-124.

8. Aifuwa, H. O., Saidu, M., Enehizena, C. O. \& Osazevbaru, A. (2019). Accounting information and lending decisions: Does sustainability disclosure matter? Copernican Journal of Finance and Accounting, 8(4), 61-89. http://dx.doi. org/10.12775/CJFA.2019.018

9. Ali, M., Ng, Y. L., \& Kulik, C. (2014). Board age and gender diversity: A test of competing linear and curvilinear predictions. Journal of Business Ethics, 125(3), 497-512. https://doi.org/10.1007/s10551-013-1930-9

10. Aman, Z. \& Bakar, N. S. (2018). The influence of board characteristics on sustainability reporting of public listed companies in Malaysia. Journal of Humanities, Language, Culture and Business, 2(7), 41-55.

11. Anazonwu, H. O., Egbunike, F. C., \& Gunardi, A. (2018). Corporate board diversity and sustainability reporting: A study of selected listed manufacturing firms in Nigeria. Indonesian Journal of Sustainability Accounting and Management, 2(1), 65-78.

12. Arora, A, \& Sharma, C. (2016). Corporate governance and firm performance in developing countries: evidence from India. Corporate Governance: The International Journal of Business in Society, 16(2), 420-436.

13. Asaolu, T.O., Agboola, A. A., Ayoola, T.J., Salamu, M.K. (2011), Sustainability in the Nigerian oil and gas sector. Environmental Management Conference Proceedings. Nigeria: Federal University of Agriculture Abeokuta

14. Awodiran, M. A. (2019). Corporate governance and sustainability disclosure: Evidence from listed industrial goods firms in Nigeria. Retrieved from https://ssrn.com/abstract=3395740

15. Ayuso, S., \& Argandona, A. (2009). Responsible corporate governance: Towards a stakeholder board of directors? Working Paper, University of Navarra, 120. 
16. Bakar, A. B. S. A., Ghazali, N. A. B. M., \& Ahmad, M. B. (2019). Sustainability reporting and board diversity in Malaysia. International Journal of Academic Research in Business and Social Sciences, 9(2), 1044-1067.

17. Bebington, J.,\& Larrinaga, C. (2014). Accounting and sustainable development: an exploration. Accounting, Organization and Society, 39(6), 395-413.

18. Bebington, J., \& Unerman, J. (2017). Achieving the United Nations sustainable development goals: an enabling role for academic research. Accounting, Auditing and Accountability Journal, Preprint, 1-24

19. Berger, A. (2019). Sustainability disclosure and the limits of diversity. Journal of EU Business School, 2, 41-60.

20. Brundtland, G. H. (1987). Our common future. United Nations world commission on environment and development (Brundtland Commission). Oxford: Oxford University Press.

21. Butler, S. R. (2012). All on board! Strategies for constructing diverse boards of directors. Virginia Law \& Business Review, 7(1), 61-96.

22. Chong, K. (2019). Pasir Gudang chemical pollution - What harm can these chemicals do to you?

23. SoyaCincau. com. In Soyacincau. Retrieved from https://www.soyacincau. com/2019/03/16/pasir-gudang-chemicalpollution/

24. Darmadi, S. (2011). Board diversity and firm performance: The Indonesian evidence. Corporate Ownership and Control Journal, 8, 450-466.

25. de Jong, M. D. \& van der Meer, M. (2017). How does it fit? Exploring the congruence between organizations and their corporate social responsibility (CSR) activities. Journal of Business Ethics, 143(1), 71-83.

26. Elaigwu, M., Ayoib, C-A., \& Salau, O. A. (2020). Board governance mechanisms and sustainability reporting quality: A theoretical framework. Cogent Business \& Management, 7(1), 1-23.

27. Emeka-Nwokeji, N. A., \& Osisioma, B. C. (2019). Sustainability reporting and market value of firms in emerging economy: Evidence front Nigeria. European Journal of Accounting, Auditing and Finance Research, 7(3), 1-19.

28. Estelyi, K.S. and Nisar, T.M. (2016). Diverse boards: why do firms get foreign nationals on their boards? Journal of Corporate Finance, 39, 174-192.

29. Fasan, M., \& Mio, C. (2016). Fostering stakeholder engagement: The role of materiality disclosure in integrated reporting. Business Strategy and the Environment.

30. Ferrero-Ferrero, I., Fernandez-Izquierdo, M. A. \& Munoz-Torres, M. J. (2015). Integrating sustainability into corporate governance: an empirical study on 
S. Musa, N. O. Gold, H. O. Aifuwa. Board Diversity and Sustainability Reporting: Evidence from Industrial Goods Firms

board diversity. Corporate Social Responsibility and Environmental Management, 4, 193-207. doi:https://doi.org/10.1002/csr.1333.

31. Font, X., Guix, M., \& Bonilla-Priego, M. J. (2016). Corporate social responsibility in cruising: Using materiality analysis to create shared value. Tourism Management, 53, 175-186.

32. Freeman, R. E. (1984). Strategic Management: A Stakeholder Approach. London: Pitman.

33. Fuente. J. A. García-Sanchez. I. M., Lozano, M. B. (2017). The role of the board of directors in the adoption of GRI guidelines for the disclosure of CSR information. Journal of Cleaner Production. 141, 737-750. https://doi.org/10. 1016/j.jclepro.2016.09.155

34. Global Reporting Initiative (2019). What is Sustainability reporting. Retrieved from https://www.globalreporting.org/information/sustainabilityreporting/Pages /default.aspx

35. Global Reporting Initiative (2013). GRI G4 Specific disclosure index https:/www.globalreporting.org/information/sustainabilityreporting/Pages/default.asp xth ash.a2xKDdYv.dpuf

36. Haladu, A., \& Beri, M. H. (2016). Corporate characteristics and sustainability reporting environmental agencies' moderating effects. IOSR Journal Of Humanities And Social Science, 21(8), 19-30.

37. Haladu, A., \& Salem, B. (2016). Board characteristics and sustainability reporting: environmental agencies' moderating effects. International Journal of Economics and Financial Issues, 6(4), 1525-1533

38. Hesselink, K. (2017). Board composition and corporate sustainability reporting quality. MSc thesis, Nijmegen School of Management, Radbound University. Netherlands.

39. Hsu, W.T., Chen, H.L. and Cheng, C.Y. (2013). Internationalization and firm performance of SMEs: the moderating effects of CEO attributes. Journal of World Business, 48(1), 1-12.

40. Hu, M. \& Loh, L. (2018). Board governance and sustainability disclosure: A cross-sectional study of Singapore-listed companies. Sustainability, 10, 1-14.

41. Ibrahim, A. H., Hanefah, M. M.(2016). Board diversity and corporate social responsibility in Jordan. Journal of Financial Reporting and Accounting, 2, 279-298. doi:https://doi.org/10.1108/JFRA-06-2015-0065

42. Ioannis, I., and Serafeim, G. (2014). The consequences of mandatory sustainability reporting: Evidence from four countries. United States of America: Harvard Business School, Harvard University. Retrieved from http://www.hbs.edu/ faculty/Publication\%20Files/11-100_7f383b79-8dad-462d-90df-324e298acb49.pdf 
43. Janggu, T., Darus, F., Zain, M. M., \& Sawani, Y. (2019). Does good corporate governance

44. lead to better sustainability reporting? An analysis using structural equation modelling. Social and Behavioral Sciences, 145, $138-145$

45. Johari, J.,\& Komathy. (2019). Sustainability reporting and firm performance: Evidence in

46. Malaysia. International Journal of Accounting, Finance and Business, 4(17), 1-7.

47. Kang, H., Cheng, M., \& Gray, S. J. (2007). Corporate governance and board composition: Diversity and independence of Australian boards. Corporate Governance: An International Review, 15, 194-207.

48. Katmon, N., Mohamad, Z. Z., Norwani, N. M \& Farooque, O. (2017). Comprehensive board diversity and quality of corporate social responsibility disclosure: Evidence from an emerging market. Journal of Business Ethics, 1-35. doi:https://doi.org/10.1007/s10551-017-3672-6

49. Khan, I., Khan, I Senturk, I. (2019a). Board diversity and quality of CSR disclosure: evidence from Pakistan. Corporate Governance, DOI 10.1108/CG-122018-0371

50. Khan, I., Khan, I., Saeed, B. (2019b). Does board diversity affect quality of corporate social responsibility disclosure? Evidence from Pakistan. Corporate Social Responsibility and Environmental Management. doi:https://doi. org/10.1002/csr.1753

51. King'ori, P. G., Naibei, I. K., Sang, H. W. \& Kipkosgei, A. K. (2019). The relationship between

52. board characteristics and environmental sustainability disclosures. International Journal of Economics, Commerce and Management, 7(9), 416-431.

53. Kyaw, K., Olugbode, M. and Petracci, B. (2017). Can board gender diversity promote corporate social performance? Corporate Governance: The International Journal of Business in Society, 17( 5), 789-802.

54. Manning, B., Braam, G., \& Reimsbach, D. (2019). Corporate governance and sustainable business conduct-effects of board monitoring effectiveness and stakeholder engagement on corporate sustainability performance and disclosure choices. Corporate Social Responsibility and Environmental Management, 26(2), 351-366. https://doi.org/10.1002/csr.1687.

55. Masulis, R., Wang, C., \& Xie, F. (2012). Globalizing the boardroom: The effects of foreign directors on corporate governance and firm performance. Journal of Accounting and Economics, 53(3), 527-554. https://doi.org/10.1016/ j.jacceco.2011.12.003 
S. Musa, N. O. Gold, H. O. Aifuwa. Board Diversity and Sustainability Reporting: Evidence from Industrial Goods Firms

56. Michelon, G., \& Parbonetti, A. (2012). The effect of corporate governance on sustainability disclosure. Journal of Management \& Governance, 16(3), 477-509. http://doi.org/10.1007/s10997-010-9160-3

57. Muñoz, E., Zhao, L., \& Yang, D. C. (2017). Issues in sustainability accounting reporting.

58. Accounting and Finance Research, 6(3), 64-71.

59. Ngu, B. S. \& Amran, A. (2018). Board diversity and materiality disclosure in sustainability reporting: A proposed conceptual framework. International Academic Journal of Economics, 5(1), 105-118.

60. Nigerian Code of Corporate Governance (2018). Handbook on code of corporate governance.

61. Lagos, Nigeria: Financial Reporting Council.

62. Nwobu, O. A. (2017). Determining corporate sustainability reporting in selected companies in Nigeria. Unpublished $\mathrm{PhD}$ thesis, College of Business and Social Sciences, Covenant University, Ota, Nigeria.

63. Ong, S. H. (2016). Measuring the quality and identifying influencing factors of sustainability reporting: Evidence from the resources industry in Australia. Retrieved from https://ro.ecu.edu.au/theses/1922

64. Onyekwelu, U. L\& Ekwe (2014). Does corporate social responsibility predicate good financial performance. ESUT Journal of Management

65. Sciences, 8(1)1-10.

66. Oxelheim, L., \& Randey, T. (2003). The impact of foreign board membership on firm value. Journal of Banking and Finance, 27(12), 2369-2392. https://doi.org/10.1016/S0378-4266(02)00395-3

67. Pfeffer, J. \& Salancik, G. R. (1978). The external control of organizations: A resource dependence perspective. New York: Harper \& Row.

68. Post, C., Rahman, N., \& Rubow, E. (2011). Green governance: Boards of directors' composition and environmental corporate social responsibility. Business \& Society, 50(1), 189-223. https://doi.org/10.1177/0007650310394642

69. Rathnayaka, M. C. S. (2018). Board involvement in corporate sustainability reporting: evidence from Sri Lanka. Corporate Governance: The International Journal of Business in Society, 18(6), 1042-1056.

70. Rhode, D. L. \& Packel, A. K. (2014). Diversity on corporate boards: How much difference does it make. DE Journal of Corporate Law Wilmington, 39, 377-383.

71. Rodríguez-Ariza, L., García-Sánchez, I., \& Frías-Aceituno, J. (2012). The role of the board in achieving integrated financial and sustainability reporting. $X V$ encuentro AECA, Ofir-Esposende (Portugal) 
72. Saidu, M \& Aifuwa, H. O. (2020). Board characteristics and audit quality: The moderating role of gender diversity. International Journal of Business \& Law research, 8(1), 144-155.

73. Saunders, M., Lewis, P., \& Thornhill, A. (2016). Research methods for business students.

74. Essex, England: Pearson Education Limited.

75. Sharif, M \& Rashid, K. (2014). Corporate governance and corporate social responsibility (CSR) reporting: an empirical evidence from commercial banks (CB) of Pakistan. Quality \& Quantity, 5, 2501-2521. doi:https://doi. org/10.1007/s11135013-9903-8

76. Studenmund, A.H. (2014). Using Econometrics: A Practical Guide (6th ed.). Harlow, England: Pearson Education Limited. United Nations SDGs (2015). Sustainable development goals. Retrieved from https://sustainabledevelopment. un.org/sdgs

77. Van Knippenberg, D., De Dreu, C. K. W., \& Homan, A. C. (2004). Work group diversity and group performance: An integrative model and research agenda. Journal of Applied Psychology, 89, 1008.

78. Zaid, M. A., Wang, M., Adib. M., Sahyouni A. \& Abuhijleh S. T. F. (2020). Boardroom nationality and gender diversity: Implications for corporate sustainability performance, Journal of Cleaner Production, (Pre-proof) https://doi.org/10.1016/ j.jclepro.2019.119652. 